\title{
Perspectives and the role of Bosnian defense industry in national innovation system
}

\author{
Benjamin Durakovic ${ }^{1}$, Erwin Trgo ${ }^{2}$ \\ ${ }^{1}$ Industrial and Mechanical Engineering, International University of Sarajevo, Bosnia and Herzegovina \\ ${ }^{2}$ Mechanical Engineering, International University of Sarajevo, Bosnia and Herzegovina
}

\begin{abstract}
*Corresponding author: bdurakovic@ius.edu.ba
(C) The Author

2020.

Published by

ARDA.

Abstract

The increased global demand for weapons is growing fast both military and civilian grade equipment. The defense industry is experiencing an increase in its trades and production over the globe. Currently global market trade of arms is about US\$ 1.9 trillion, with a trend of increase. This paper investigates global trends in defense through analysis of global defense spending and R\&D activities with the focus to Bosnian defense industry perspectives. It was observed that Bosnian defense industry has potential to be one of the key players of the national innovation system through which the national R\&D output would make notable positive impact on the national economic performances.
\end{abstract}

Keywords: Defense industry; R\&D investment; Innovation; National innovation system

\section{Introduction}

Over the past decade, the international transfer of weapons has significantly increased with the leaders in the export being the United States, China, Russia, France and Germany, and the largest importers being India, Egypt, Saudi Arabia, and the United Arab Emirates (UAE) [1]. Highly influential companies in the industry when it comes to weapon sales are those from the US and the Western Europe. In 2016, the combined sales amount from those two areas was USD 194.8 billion. Overall, the country with the most influence on overall weapons sale trends is undoubtedly the US [2].

The defense industry is an element for reaching the potential sustainable economic growth of a country. Due to the policies a country chooses to pursue, it is decided if and how many resources would be allocated for the defense industry in total [3]. One of the basic concepts of the economics is that producing larger quantities of one commodity would result in producing smaller quantities of another commodity. This means that increased spending in military area would cause lower spending in civilian area. Also, economic growth at the local level is impacted by the defense industry as many people depend on the jobs and incomes possibilities created in this industry.

Defense industry is an essential component in providing security for a country while it eliminates the threat posed by other countries, both in terms of hostility and in terms of imposing their products that would be implemented over the domestic products of a country.

Moreover, security threats encourage the increase in the development of this industry. In conclusion, defense industry development is the consequence of the overall increase in the country's total industry production [3][4].

Throughout history, the defense industry was seen as a strictly military branch of industry. Nowadays it has developed in almost every sphere of our life. The industries operating in this branch have shifted from specialization production to companies which became conglomerates, producing everything for naval, air and land equipment's and arms.

This work is licensed under a Creative Commons Attribution License (https://creativecommons.org/licenses/by/4.0/) that allows others (c) (i) to share and adapt the material for any purpose (even commercially), in any medium with an acknowledgement of the work's authorship and initial publication in this journal. 
The goal of this paper to investigate perspectives of Bosnian defense industry in national innovation system as well as global trends and local Bosnian defense sector opportunities for generating significant added value through customized innovative solution for targeted global market. National innovation system is defined as “...set of distinct institutions which jointly and individually contribute to the development and diffusion of new technologies and which provides the framework within which governments form and implement policies to influence the innovation process. As such it is a system of interconnected institutions to create, store and transfer the knowledge, skills and artefacts which define new technologies" [5]. The defense industry is primarily a business with the main objective to maximize profit with minimal investments. Also, Bosnian defense industry has all potential to be recognized as one of the strategic industries for the development of the country.

\section{Top global market trends}

For the purpose of this research, global trends are reflected in two directions: spending trends and R\&D trends. Global defense spending continues to increase despite financial pressure due to COVID-19. The global defense spending for period 1988 - 2019 is shown in Figure 1.

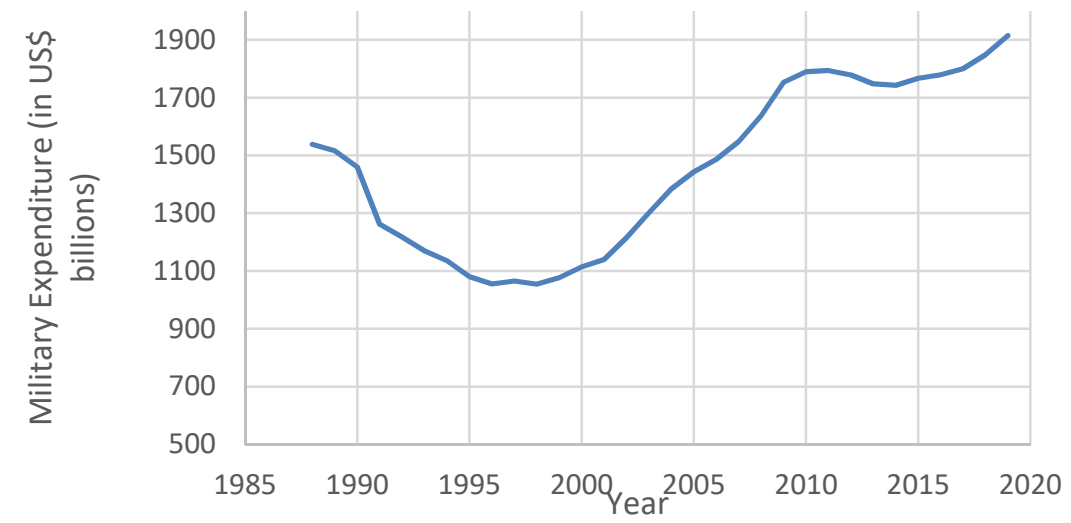

Figure 1. Global defense spending for period $1988-2019^{1}$

The demand for military equipment is growing as governments around the world focus on military modernization busting worldwide defense expenditure. Global defense spending reached US\$1.914 trillion in 2019, and continue to grow in 2020 for about $3.9 \%$ despite coronavirus pandemic.

To identify general trends in different weapons deliveries and to permit comparison between the data, Stockholm International Peace Research Institute (SIPRI) developed a unique system to measure the volume of international transfers of major conventional weapons using a common unit, the trend-indicator value (TIV). The TIV trends of total arm transfer for period 1950-2019 is presented in Figure 2.

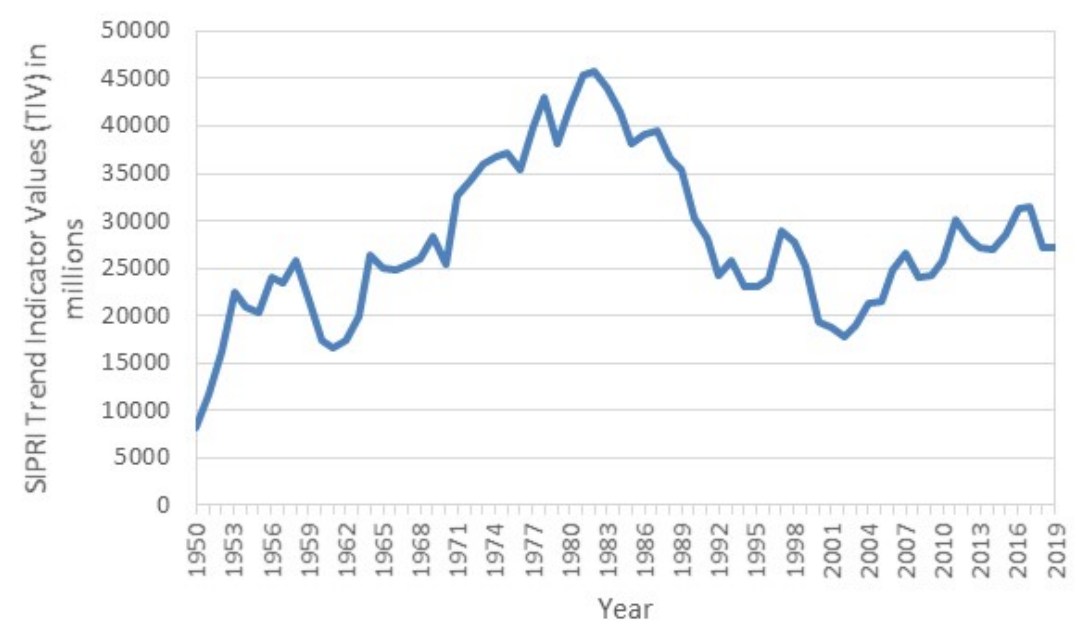

Figure 2. Total arms transfers for period $1950-2019^{2}$

\footnotetext{
${ }^{1}$ SIPRI Military Expenditure Database, https://www.sipri.org/gallery/military-spending-graphics-2019
} 
It is observed that TIV had been growing over the time until it achieved a peak in 1982. In period between 1982 and 2002 the TIV was significantly decreased. Since 2002 the TIV has been growing until now. It is expected that COVID-19 will slightly slow the TIV growth in upcoming period.

The trends in R\&D are focused on the artificial intelligence systems, additive manufacturing, as well as cost reduction. Future weapons are not something so Sci-Fi nowadays. Electric rifles, advanced magnetic armor, robot soldiers, etc. are all being devised today by big, both public and private institutes [6].

Defense is interested in technologies, systems and processes that improve intelligence collection, analysis and dissemination across all capabilities within Defense and in all domains: land, maritime and aerospace. This includes the advanced use of biometric data, as well as innovation in cyber technology to support every facet of capability development.

Supporting the shift from Intelligence, Surveillance and Reconnaissance to Targeting, as well as the advancement of hypersonic technology as an opportunity for Defense's space capabilities also warrant attention in this stream. The relevancy of smart defense in modern international security has been on NATOs list ever since 2008 financial crisis [7].

\subsection{Artificial intelligence}

Global market trends are important indicators for the contractors or companies in the global market as the more updated one is the more market area can be covered. According to case studies done [8], the defense industry shifts towards robotics, cyber weaponry and automated complex systems [9].

Starting with the main technological trends, artificial intelligence (AI) has certainly become a great tool for defense industry in the sense of processing large amounts of data with which organizations have struggled over the past few years. Data processing done by AI allows people to shift their focus on the results and findings in contrast to primarily producing them. Advanced robots and augmented reality are some similar paths companies are already taken interests into with heavily investments already being taking places.

\subsection{Additive manufacturing}

3D printing has become a huge disruptor ever since 2017. The militaries are already looking into the potential of printing spare parts and military equipment in-theatre to drive down costs and drive-up availability. The aerospace and defense $(A \& D)$ sector is set to become one of the biggest contributors to 3D printing's global revenues, predicted to reach a mammoth $\$ 1.4$ billion by 2019 , producing parts in-house, a development that will completely reshape the relationship between contractors and manufacturers [10], [11].

\subsection{Cost reduction}

Another trend is cost technology. Clean technology measures within the A\&D sector include energy efficiency, waste management, recycling, use of digital and paperless products, video conferencing, and many more. According to well defined research the budget for the global defense clean technology market will increase $7.5 \%$ between 2016 and 2021. This also includes paperless documents and clean power. A difficulty defense companies face as they try to move forward with these environmentally friendly technology initiatives will be integration with current systems. However, the savings over the long run from eco-friendly and costeffective solutions are worth the initial investment.

Cost-effectiveness can be listed as the back bone of all the major trends. Innovation is the key factor in this industry and those who are willing to adapt are those who survive. Technology investments are elements that enable manufacturers to innovate on-the-go. These improvements should lower manufacturers' costs and help them stay a relevant member of the industry.

Companies in sectors of the healthcare, software and internet show the substantial grow in the R\&D spending over the last fifteen years, while typically spend less on R\&D and it has been largely flat over recent years.

\footnotetext{
${ }^{2}$ Source: SIPRI Trend Indicator Values (TIVs), http://www.sipri.org/databases/armstransfers/sources-andmethods/
} 
Companies from South Korea, Israel, Europe, Japan, North America and China demonstrate the most significant growth in R\&D spending.

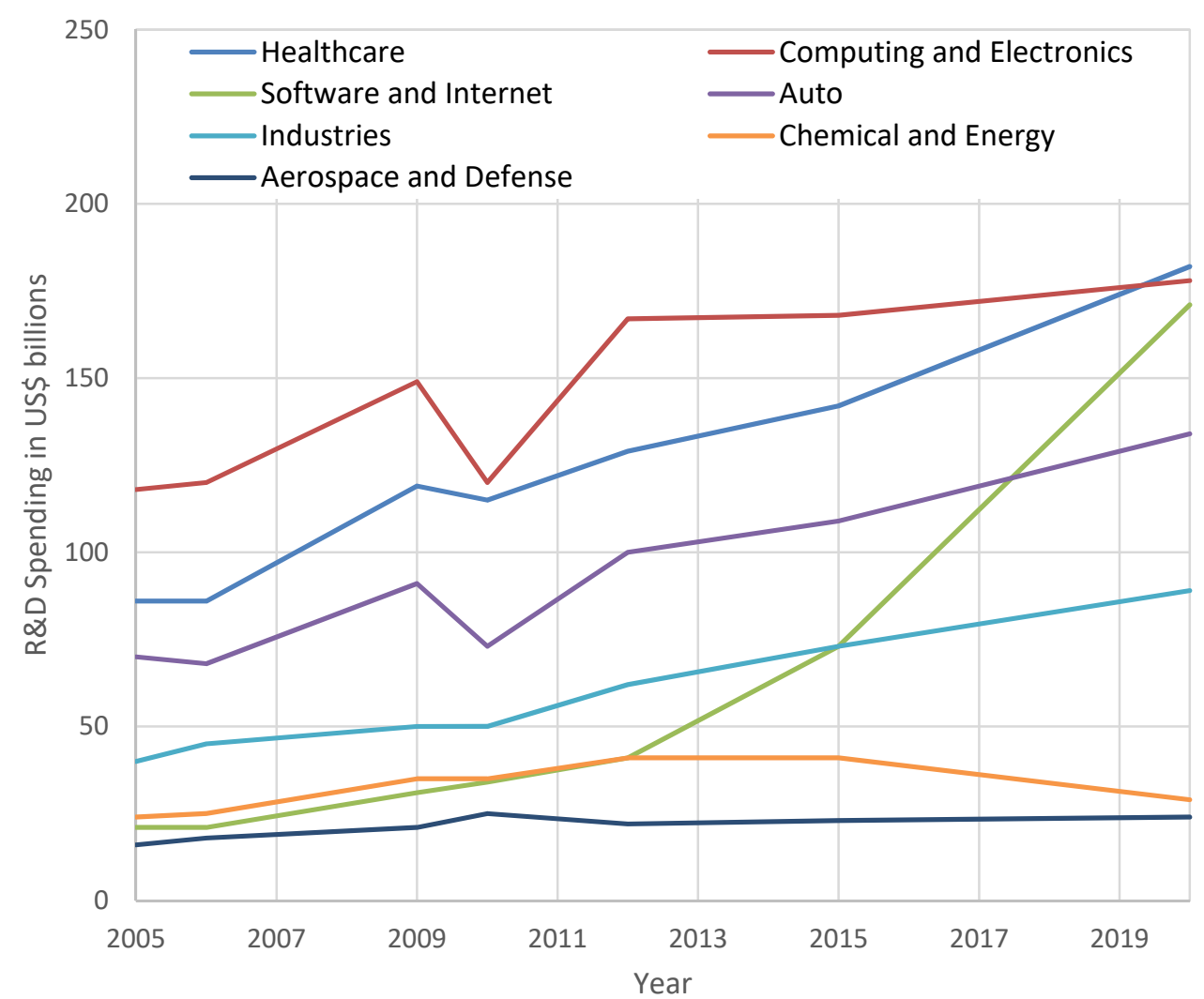

Figure 3. R\&D spending by industry ${ }^{3}$
Healthcare

Computing and Electronics

Software and Internet

Auto

Industries

Chemical and Energy

Aerospace and Defense

\section{Current state and trend in Bosnian defense industry}

As result of increased global defense spending, in recent years turnover of Bosnian defense industry started to grow. Reports say that the total income has increased for $21 \%$ and the total export has increased for $29 \%$ when compared to 2015 [12]. The Defense industry is mainly based on the production of ammunition and artillery pieces. This is far away from the time when Bosnia as a part of Former Yugoslavia, produced a wide variety of both complex and non-complex products. Being a war-ravaged transition country, the reduction in production is not something out of the ordinary.

Ukraine, as one of the world's super power in weapon production, experienced a huge decrease in every branch of their defense industry in their transition period of 1991 to 1999 [13]. Through investments in R\&D and through arms export to $3^{\text {rd }}$ world countries, Ukraine's defense industry rocketed sky high again. Although a small country, with small influence, Bosnia can allocate the steps which Ukraine undertook in order to get its industry back in its tracks.

Representative products of Bosnian defense industry [14], [15]:

- All kinds of small-arms ammunition, ranging from cal. 5.56 to $12.7 \mathrm{~mm}$

- Artillery howitzers and mortar systems

- Artillery ammunition, ranging from 75 to $152 \mathrm{~mm}$

- Mortar ammunition, ranging from 60 to $120 \mathrm{~mm}$

- Fuses and cartridges

- Observing and sighting equipment

- Uniform and soldier protection equipment (Military vests, Helmets, Riot control equipment, Boots)

Recently developed:

- Self-propelled howitzer $155 \mathrm{~mm}$ with fully automatic loading (prototype made)

${ }^{3}$ Source: Capital IQ data, Strategy and analysis 
- Light Armored Vehicle

- Gun $9 \mathrm{~mm}$ and rifle $7.62 \mathrm{~mm}$

- $\quad$ RPG 7

Following the world defense industry trends and investing in R\&D, Bosnia can take a piece of the world trade cake. Recently, Bosnia developed its first fully automatic, mobile artillery piece. It complies with NATO standards, is lighter than its French and Serbian competition and is ought to cost less than its counterparts. The manufacturer BNT Novi Travnik, devised everything except the sophisticated electronics and the truck [14]. Analyzing the portfolio of local defense industry, it is observed that only recently developed self-propelled howitzer is on the track with global R\&D trends. To be on the track with the global R\&D trends in defense, a significant upgrade of the existing product is required, and development of solution for the global market.

To asses alignment of Bosnian defense sector with the global trends, SWOT analysis is done and the results are provided in Table 1.

Table 1. SWOT analysis of Bosnian defense industry

\begin{tabular}{|c|c|}
\hline Strengths & Opportunities \\
\hline $\begin{array}{l}\text { Tradition in making weapons and other metallurgy } \\
\text { products } \\
\text { Reliable, battle tested products } \\
\text { Skilled workforce } \\
\text { Brand }\end{array}$ & $\begin{array}{l}\text { Growth in global defense spending } \\
\text { Growing trends in smart weapon ammunition } \\
\text { Artificial Intelligence } \\
\text { Autonomous complex systems } \\
\text { Bio Design } \\
\text { Drones } \\
\text { Laser-based weapons } \\
\text { To become strategic industry for Bosnian economy }\end{array}$ \\
\hline Weaknesses & Threats \\
\hline $\begin{array}{l}\text { Insufficient investment in R\&D } \\
\text { Lack of knowledge needed for the creation of more } \\
\text { complex weapon systems } \\
\text { Little or no R\&D }\end{array}$ & $\begin{array}{l}\text { Lack of political stability } \\
\text { Current world policies } \\
\text { World competitors }\end{array}$ \\
\hline
\end{tabular}

As previously explained, the strengths are analyzed as one of the internal elements of this analysis. In this case, strengths of the Bosnian defense industry are tradition in making weapons and other metallurgy products, reliability of products and proven brands. On the other hand, weaknesses of the industry could either be lack of knowledge regarding producing complex weapon systems, as well as insufficient investment in research and development, which are driving forces of industry growth. Tapping into the area of drones, or Artificial Intelligence based systems could be considered as opportunity of defense industry of Bosnia, while the competitors and potential political instability as well as new global policies on defense products and distribution are perceived as threats of the industry.

Along with the pharmaceutical industry, local defense industry has potential to become one of the key sectors of the Bosnian innovation system. Innovations are key factors to generate significant added-value, to improve economic performance and to ensure business future.

Opportunities lie in global defense spending growth, growing trends in smart weapon ammunition, autonomous complex systems, artificial Intelligence, drones. Spending in defense sector on global level is continuously and significantly grooving, therefore this sector should become one of the strategic industries for the Bosnian economy and country development. This is an opportunity to invest in end-user-solutions on the global market through this industry, which will have significant added value and a significant share of knowledge. 
Comparing the current production program from the Bosnian defense industry with global trends, it is observed that significant upgrade is required to keep pace with global trends, which requires significant investment in research and development. Therefore, potential investors as well as the government should recognize their interest in this sector, explore and encourage investors to invest. The R\&D expenditure for selected countries as percentage of GDP for period 1996 - 2019 is shown in Figure 4.

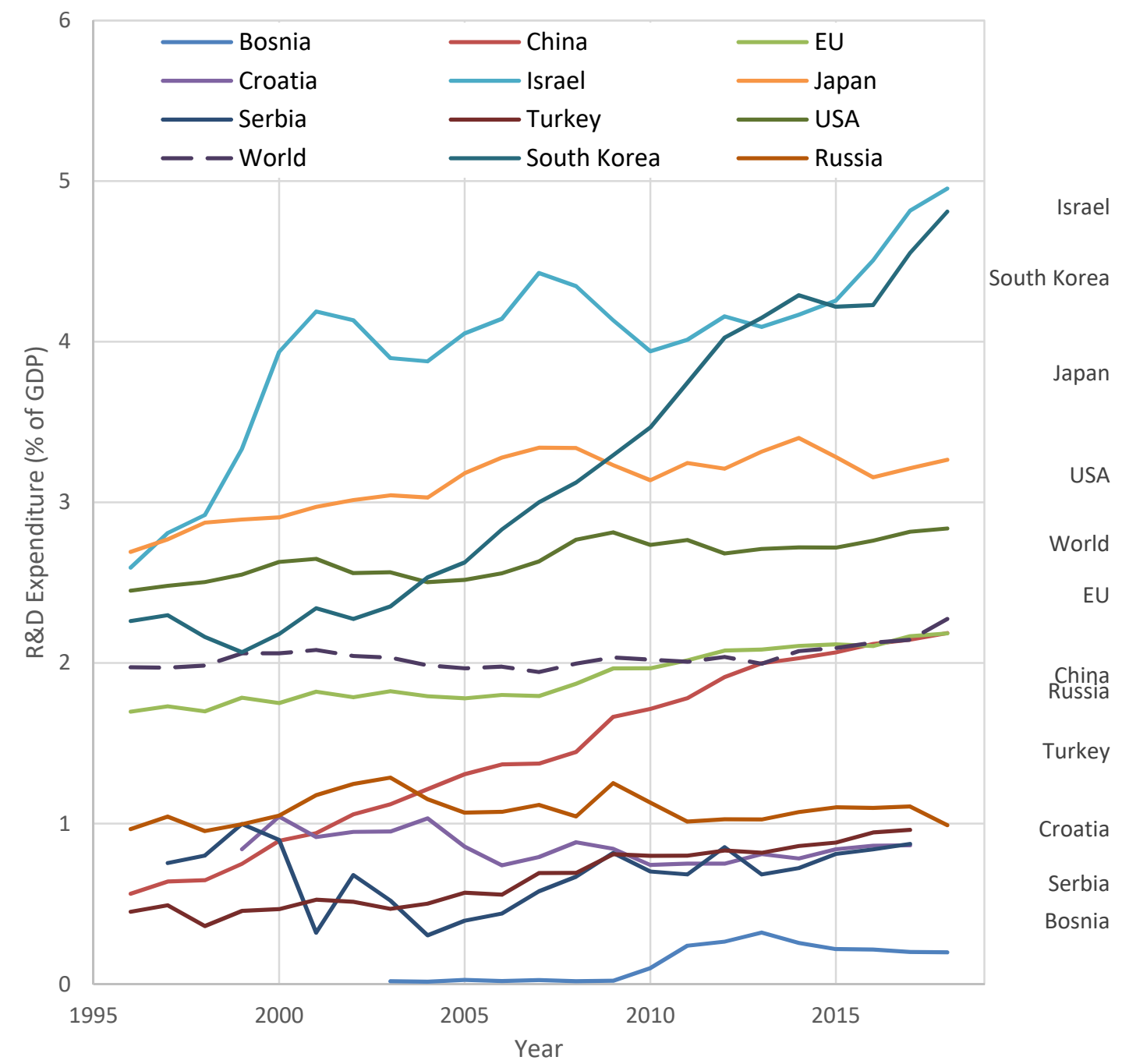

Figure 4. R\&D Expenditure in Bosnia and for selected countries ${ }^{4}$

Recent spending on R\&D projects in Bosnia are one of the lowest in the world as well as the lowest in the region. Companies and government from Bosnia spend less than $0.2 \%$ of GDP on R\&D projects, which is about 5 times lower than regional average (compared with neighboring countries) and about 15 times less that the average of top global investor in R\&D. To improve economic performance of Bosnian defense industry, investment in $R \& D$ is necessary, since there is significant positive correlation between investment in $R \& D$ and economic performance [16].

Over the last decade South Korea has the highest grow in R\&D spending as percentage of GDP. Reforms which took place in South Korea would be a good model of restructuring the defense industry and the military in general [4]. Making strategic alliances with countries that are already producing sorts of smart weapons would be an important step in the development of a domestic smart weapon or ammunition. Obtaining the knowledge through partnerships with countries which are leaders in the market, Bosnia would be able to become a regional factor in the production of smart weapons. A good example could be the Israel, Spain and Portugal, which became regional leaders in arms production through investments in R\&D, but also through their acute strategic need [17].

${ }^{4}$ The World Bank, https://data.worldbank.org/indicator/GB.XPD.RSDV.GD.ZS 
As already stated, Bosnia's ammunition products are already used in many nations, all over the world. They are less expensive but battle proven and reliable. So, there is a solid turf at which Bosnia can aim their sights. Following trends and further developing the production of arms, increases interest in products which are made in Bosnia. Cooperation between partners countries can definitely lead them to a profound and well-established $R \& D$ and manufacturing industry for the defense systems. For instance, in the US most of the R\&D investment were made by business, which is shown in Figure 5.

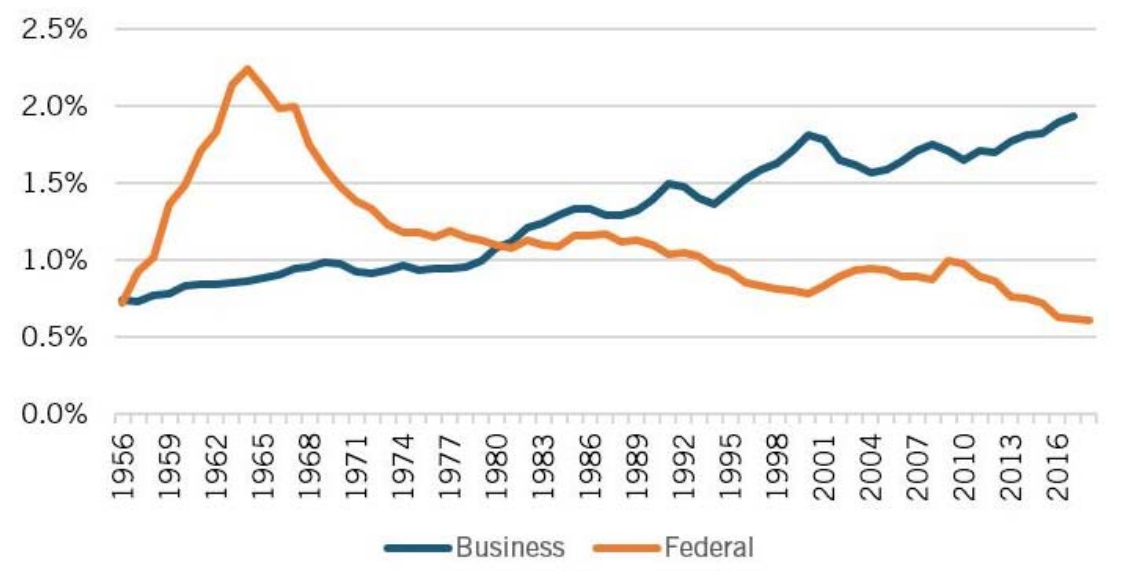

Figure 5. History of R\&D Expenditure in the US by business and government [18]

Recently the business share in the US R\&D expenditure is about $67 \%$ of total GDP for R\&D, while the government is about $33 \%$ [18].

\section{Conclusion}

Opportunities for Bosnian defense industry in global trends are analyzed. The defense industry is primarily a business, and as in every business the main objective is to maximize profit with minimal investments. Bosnia is a small country and has negligible influence in the global market of arms. This can be considered as an advantage for Bosnian defense sector to be specialized on customized solutions for narrow global market rather than modular ones. Customized solutions for narrow global market might be less interesting to big players, which could make some room for Bosnian defense industry. Current rate of expenditure in the R\&D sector is not fare below world average, as well as far below regional average. To bridge the gap between the desire to invest in R\&D and the provision of the necessary funds, the public private partnership model could be one with an emphasis innovative solution. In order to achieve this, it is necessary to recognize the domestic defense sector as a strategic branch for economic development. Opportunities lie in growing of global expenditure for the defense products and positive trend in artificial intelligence systems. Tradition in making weapons and other metallurgy products, reliable battle proven products and skilled workforce are major strengths. Among the other domestic sectors, the defense industry along with pharmaceutical has the potential to deliver via R\&D end user solutions, which qualifies them to generate increased added-value through the knowledge and branding. Therefore, the defense industry through the R\&D output may play a key role in the national innovation system and achieve notable positive impact on the national economic performances.

\section{References}

[1] Pieter D. Wezeman, Dr Aude Fleurant, Alexandra Kuimova, Dr Diego Lopes da Silva, Dr Nan Tian, and Siemon T. Wezeman, "Trends in International Arms Transfers, 2019," 2020.

[2] Aude Fleurant, Sam Perlo-Freeman, Pieter D. Wezeman, Siemon T. Wezeman, and Noel Kelly, "The SIPRI Top 100 arms-producing and military services companies, 2015," 2016.

[3] A. Kuah and B. Loo, "No. 70 examining the defence industrialization-economic growth relationship:the case of singapore with Compliments," 2004.

[4] J. Carlos and O. Torrenova, "Global defence industry and the asia-pacific region," 2012.

[5] METCALFE and S., "The Economic Foundations of Technology Policy: Equilibrium and Evolutionary Perspectives," Handb. Econ. Innov. Technol. Chang., 1995, Accessed: Mar. 04, 2021. [Online]. Available: https://ci.nii.ac.jp/naid/10021355612. 
[6] C. DeNicolo and A. Herbert, "Industry Top Trends 2017 Aerospace and Defense Overview," 2017.

[7] I. D. Ivanov, "The diffusion of NATO partnerships and their effect on Alliance's smart defense." Accessed: Mar. $2021 . \quad$ [Online]. Available: https://www.academia.edu/2022709/The_diffusion_of_NATO_partnerships_and_their_effect_on_Alli ance_s_smart_defense.

[8] UK Ministry of Defense, "Sustainable MOD Strategy 2015-2025.” Accessed: Mar. 16, 2021. [Online]. Available: Sustainable MOD strategy 2015 to 2025 - GOV.UK.

[9] V. Boulanin and M. Verbruggen, "Mapping the Development of Autonomy in Weapon Systems," Stockholm, 2017.

[10] "Three key trends hitting the defence industry in 2017 - defenceWeb." https://www.defenceweb.co.za/joint/science-a-defence-technology/three-key-trends-hitting-thedefence-industry-in-2017/?catid=74\&Itemid=30 (accessed Mar. 16, 2021).

[11] "Becoming a Digital Frontrunner in Aerospace and Defense." https://www.bcg.com/publications/2017/transformation-becoming-digital-frontrunner-aerospacedefense (accessed Mar. 16, 2021).

[12] "Trends in World Military Expenditure, 2019 | SIPRI." https://www.sipri.org/publications/2020/siprifact-sheets/trends-world-military-expenditure-2019 (accessed Mar. 16, 2021).

[13] A. J. K. Bailes, O. Melnyk, and I. Anthony, "Relics of Cold War: Europe's Challenge, Ukraine's Experience | SIPRI," 2003. Accessed: Mar. 16, 2021. [Online]. Available: https://www.sipri.org/publications/2003/sipri-policy-papers/relics-cold-war-europes-challengeukraines-experience.

[14] "BNT TMH TMIH - Tvornica masina i hidraulike Novi Travnik BRATSTVO vojna industrija BIH TMIH TMH. Bosnia and Herzegovina | BNT-Tvornica mašina i hidraulike, Novi Travnik." http://www.bnt-tmh.ba/vojni-program/ (accessed Mar. 16, 2021).

[15] “Unis Group - Bosnian Defence Industry.” https://www.unisgroup.ba/ (accessed Mar. 16, 2021).

[16] Ü. Ampirik and B. Analiz, "PARADOKS Ekonomi, Sosyoloji ve Politika Dergisi PARADOKS Economics, Sociology and Policy Journal Relationships Between R\&D and Corporate Performance: An Empirical Analysis in Istanbul Stock Exchange Ar---Ge Ve Firma Performansi Arasindaki İlişki: Borsa İstanbul," 2016.

[17] J. Brauer, "The Arms Industry in Developing Nations: History and Post-Cold War Assessment," in Arming the South, Palgrave Macmillan UK, 2002, pp. 101-127.

[18] R. D. A. Caleb Foote, "Federal Support for R\&D Continues Its Ignominious Slide." Information Technology and Innovation Foundation, 2019, Accessed: Mar. 04, 2021. [Online]. Available: https://itif.org/publications/2019/08/12/federal-support-rd-continues-its-ignominious-slide. 